\title{
Analysis of Students' Science Process Skills on the Concept of Material Classification and its Changes in the Junior High School
}

\author{
Feby Unggul A K SEJATI ${ }^{1}$, Sulistyo SAPUTRO ${ }^{2}$, Nurma Yunita INDRIYANTI ${ }^{3}$
}

\section{ARTICLE INFO}

\section{Article History:}

Received 03.05.2019

Received in revised form

27.12.2019

Accepted

Available online 01.01.2020

\begin{abstract}
This study aimed to describe the science process skills (SPS) possessed by students, as well as how to empower them for students. These skills were measured using written assessment instruments. The research method used in this research was descriptive. Data collection instruments in this study were multiple-choice test instruments. The research subjects were 38 students of VII class, consisting of 23 females and 15 males in one of the junior high schools in the City of South Tangerang, Banten, Indonesia. The results showed the reliability of the test questions was 0.76 with a high category; the level of difficulty, which was in the medium category, was as many as 20 questions, and eight questions included in the category of easy and difficult. The distinguishing features of the questions belonged to a quite good category. The SPS owned by students gained an average of $61 \%$, which means in the good category. The SPS empowerment of students can be done with learning models, methods, and approaches that support it, such as the Project base learning, Inquiry, and Problem base Learning experimental methods, and scientific approaches.
\end{abstract}

(C) IJERE. All rights reserved

Keywords: ${ }^{1}$

Science Process Skills, assessment instruments, natural sciences.

\section{INTRODUCTION}

The development of the 21st century has caused intense competition in various aspects of life, not least in the world of education. The world of education is required to prepare students who can compete nationally or globally. The demand is inseparable from the necessity to be able to improve the knowledge and skills of students to face every challenge that exists. Responding to the existing challenges, the Indonesian government implements the 2013 curriculum. The application of the 2013 curriculum is expected to answer every challenge demanding a paradigm shift from teacher-centered to student-centered. This process is carried out by changing the direction of learning to be interactive, passive learning to be active, isolated to networking, and learning itself becomes more collaborative (groups)(Wisudawati \& Sulistyowati, 2015).

\section{The situation of the Problem}

As explained earlier, the skills aspect is one of the things that need to be developed in the 21st century. These skills are skills in thinking and learning. Some skills are needed, namely, skills in critical thinking, problem-solving, collaboration, and communication. Besides, good science process skills are also needed to support other skills. Therefore, science process skills are essential skills that must be mastered in order to face competition in this century (Widodo, Rachmadiarti, \& Hidayah, 2017).

Science process skills (SPS) are skills needed to acquire and organize environmental knowledge based on knowledge and experience using scientific methods (Hırça, 2012; Aslan, 2015). SPS is also seen as a unity that is inseparable from the attitude, physical, and ability of a person to learn science effectively(Akinbobola \& Afolabi, 2010). SPS, in this case, is also used in developing and applying the concepts, principles, and laws of science. The intended SPSs are not only physical skills but also mental and social skills (Rustaman, 2005). In other words, SPS functions to build knowledge theoretically, but can also be used in everyday life.

SPS is classified into two types, namely, basic SPS and integrated SPS (Subali, 2015; Remziye Ergul et al., 2011) Basic SPS, according to Delen \& Kesercioğlu (2012), is a skill that consists of observation, classification, measuring with standard scale, inference, prediction, and communication. In addition, Rezba, Sprague, \& Flel (2003)describe that integrated SPS consists of identifying research variables, compiling tables from observational data, describing graphs of research results, describing relationships between variables, obtaining and processing data, analyzing experiments, compiling hypotheses, defining variables operationally, designing investigations, and conducting experiments. 
These aspects of SPS can help improve students' thinking abilities. One of them is the observing aspect which requires students to be able to use all their senses. The use of all these senses will help students think more complex than before (Jones et al., 2003). This improvement can then help students better master the skills requested in the 21st century (Turiman, Omar, Daud, \& Osman, 2012). Therefore, SPS training needs to be done so that students have a basis in developing skills that are the demands of the 21st century (Turiman et al., 2012; Khaeruddin, Mohamad Nur, 2016). However, before the training is conducted, it would be better to do an analysis first about the SPSs owned by students. It can be used as a basis for teachers to prepare the correct formula in accordance with the student's initial SPS. One of the things that can be done is to measure student SPS (Khaeruddin, Mohamad Nur, 2016).

The concept of the material and its changes in this study were chosen based on the value of the absorption of national examinations (UN). The value of UN absorption, in this case, illustrates students' knowledge of the material being tested. The concept of material classification and changes were chosen because it still has a low UN absorption value below $55 \%$. The low value of absorptive capacity is found in 2 of the $3 \mathrm{UN}$ indicators on this concept, namely the separation of mixtures and differences in chemical and physical changes. The assumption of selecting a concept that has a low UN score is to confirm the relationship of students 'knowledge with the students' knowledge process skills in the aspect of knowledge. In addition, the material on the concept of material classification and its changes also requires students to have a good SPS in understanding it (Jumadi, Sunarno, \& Aminah, 2018).

\section{Aim of the Study}

The things that have been presented previously became the objectives of this research. The purpose of this study was to analyze the science process skills possessed by students on the concept of material classification and its changes. The analysis carried out, in this case, described not only the measured SPS but also the ways that could be taken in empowering students' SPS.

\section{METHOD}

The descriptive method was the method used in this study. This method is a method that describes a phenomenon without providing treatment. It means that this method describes an event or phenomenon as it is (Sukmadinata, 2012). This research was conducted in August-September 2019. Technical analysis of the data in this study was to compare the scores obtained by students with an ideal score, which was then multiplied by $100 \%$. The results of the analysis were then described as quantitatively and qualitatively.

\section{Material}

The subjects in this study were eighth grade students at SMP Negeri 17 Tangerang Selatan who had an average age of 13-14 years. Subjects were selected by purposive sampling technique based on the needs of researchers. The total number of subjects in this study were 38 students consisting of 23 women and 15 men. Data collection instruments were in the form of multiple-choice test instruments. The instrument was tested for eligibility before being used with the reliability test, the difference power, the deception index, and the level of difficulty of the test items. The feasibility test was analyzed using Anates V4. A clearer example of the instrument used in measuring student SPS is presented in Figure 1.

\begin{tabular}{|c|c|c|c|c|c|c|c|c|c|c|}
\hline \multirow{2}{*}{$\begin{array}{l}\text { Indicator of } \\
\text { Material } \\
\text { Achievment }\end{array}$} & \multirow{2}{*}{$\begin{array}{l}\text { Indicator of } \\
\text { Science Process } \\
\text { Skills }\end{array}$} & \multirow{2}{*}{$\begin{array}{l}\text { Type of } \\
\text { Knowledge }\end{array}$} & \multirow[t]{2}{*}{ Item Question } & \multirow{2}{*}{$\begin{array}{l}\text { Answer } \\
\text { Key }\end{array}$} & \multicolumn{6}{|c|}{$\begin{array}{l}\text { Bloom's Cognigtive Taxonomy } \\
\text { Level and Number Of Question }\end{array}$} \\
\hline & & & & & C1 & C2 & $\mathrm{C}_{3}$ & $\mathrm{C}_{4}$ & $\mathrm{C}_{5}$ & C6 \\
\hline $\begin{array}{l}3.3 .1 \\
\text { Classifying } \\
\text { material } \\
\text { characteristics }\end{array}$ & Observation & Conceptual & Consider the following picture! & C & & 1 & & & & \\
\hline & & & $\begin{array}{l}\text { Which statement is in accordance with the picture } \\
\text { above? } \\
\text { a. It has a liquid, has a mass, has a fixed shape }\end{array}$ & & & & & & & \\
\hline
\end{tabular}

Figure 1. Sampel of Test Instrument

\section{Data Analyses}


Test assessment analysis was obtained with the students answering multiple-choice questions, with correct score $=1$ and false score $=0$. The results of the test assessment analysis would be used to determine the overall science process skills based on aspects of knowledge. The value obtained would be calculated using the equation:

$$
\text { The value of each SPS aspect item }=\frac{\text { The number of correct answers for all students }}{\text { the number of students }} \times 100 \%
$$

The next analysis that was carried out was to look for the value of each aspect of the SPS. As for the equation is as follows:

$$
\text { Values of SPS aspects }=\frac{\text { The sum of the values for each item about aspect } X}{\text { Number of items in aspect } X}
$$

\section{FINDINGS}

\begin{tabular}{|c|c|c|}
\hline SPS Aspects & The value obtained (\%) & Category \\
\hline Observation & 60 & Enough \\
\hline Classification & 62 & Good \\
\hline Prediction & 50 & Enough \\
\hline Asking & 51 & Enough \\
\hline Composing Hypothesis & 68 & Good \\
\hline Designing Experiments & 53 & Enough \\
\hline Using Tools & 67 & Good \\
\hline Interpretation & 73 & Good \\
\hline Applying the Concept & 57 & Enough \\
\hline Communicating & 68 & Good \\
\hline Average & 61 & Good \\
\hline
\end{tabular}

Table 1. Values of Observed SPS Aspects

Table 1 shows that the measured SPS of the students got an average of $61 \%$ with a good category. It means that students' SPS mastery is generally good. However, there are still some aspects of SPS that fall into the sufficient category, namely aspects of observation, prediction, asking questions, designing experiments, and applying concepts.

\section{RESULT, DISCUSSION, AND SUGGESTIONS}

This section describes the results of science process skills (SPS) on the subject of material classification and changes. Ten SPS indicators were measured, namely 1) observation, 2) classification, 3) predictions, 4) asking questions, 5) preparing hypotheses, 6) designing experiments, 7) using tools and materials, 8) interpretations, 9) applying concepts and 10 ) communicating. Each of these skill indicators was represented by three questions on the selected multiple-choice test instrument. Before talking further about the measured SPS results, it is explained first about the appropriateness of the test instruments used in terms of test reliability, differentiation power, deception index, and item difficulty level.

The reliability of the test, in this case, was related to whether or not the questions were made with periodic trials. The reliability of the questions obtained from the test results was 0.76 , which could be categorized as high (Rostina, 2014). Different power from the questions that had been made included in the category enough, good, and very good. It means that the questions could distinguish between the upper and lower groups quite well. The level of difficulty made in the questions 22 of 30 questions included in the medium category and the rest included in the category of easy and difficult. The number of questions in the medium category showed that the questions made could be submitted to students in the high and low categories.

The first SPS aspect that was included in the sufficient category and needed to be improved was the observation aspect. This observing skill is a student's skill in using the five senses in observing an object or phenomenon that occurs. In addition, this skill is also related to the ability to use relevant and adequate facts from an observation (Rustaman, 2005). The results showed that in general, students had not been able to observe the material change events that occurred in a phenomenon in everyday life. Students were asked to determine the events that occurred in the water when the clothes were dried and dominantly chose the wrong answer choices. This result indicates that the students' skills are not optimal in observing a phenomenon. Therefore, it is necessary to dissect and improve the skills of this observing aspect. It is 
because the skills of observing aspects are the basic skills that students must master very well (Safaah, Muslim, \& Liliawati, 2017)

The next aspect that was measurable and needed to be improved was the prediction aspect. The aspect of prediction relates to students' skills in estimating a possibility or tendency based on data or observations (Rustaman, 2005). Students are said to have this skill if they can express something that might occur based on patterns of previous observations (Safaah et al., 2017). The results of this study showed that students' ability to predict was still in a sufficient category in the two questions presented. On average, students could predict only $40 \%$ of the total research subjects.

The aspects of asking, applying concepts, and designing experiments were also included in enough category. The questioning aspect was mastered by $50 \%$ of students. In this case, students were asked to choose the appropriate question for the answers given. Mastery by half of the number of subjects indicates the need for empowerment for this aspect. The ability to ask is an essential ability of students because it is related to curiosity about something. These skills relate to skills in asking for an explanation of what, how, why, when, and where about an event or phenomenon (Rustaman, 2015). Designing experiments were also included in the aspects which were quite sufficient. There were two questions out of three questions that were still below $50 \%$; the questions raised were about the separation technique suitable for the given sample and the principle of the settling method. The aspect of applying the concept to the last aspect was included in enough category. One in four questions raised had a very low score of $18 \%$. Questions raised were about changing nails dipped in water.

In general, student SPS test results indicate that there was a need to improve some aspects of the SPS. It is because the results of the tests carried out still have a small percentage. One indication of the cause of the lack of science process skills in students is inappropriate learning strategies. It is in line with the results of Al-Rsa'i, Al-Helalat, \& Ali Saleh (2017) research, which states that learning strategies affect the science process skills possessed by students. The observations showed that the teacher still used expository learning strategies. As is well known, this strategy is a learning strategy that is still teacher-centered. It is not in accordance with the demands of the 2013 curriculum, which mandates the use of inquiry learning strategies.

The use of inquiry learning strategies can change teaching patterns that were previously teachercentered to student-centered. This change is vital to provide an effective learning environment. It is also expected to improve the skills of students, especially science process skills possessed. It is in line with the opinion of Wright (2011), who states that student-centered learning will create an effective learning environment in order to achieve the expected goals. The purpose of learning, in this case, is to improve the learning processes undertaken. Student-centered learning can also help students independently build their knowledge. It supports the theory of constructivism learning that considers students as active agents in the process of knowledge acquisition (Olusegun, 2015).

Several things can be used to improve students' science process skills, one of which is to choose the right model, method, and approach. The right model is a model that can empower SPS and requires SPS learners in each step of their learning. These models are student-centered, as explained previously. There are several models that can be used, namely the inquiry and PBL models (Muliyani, Kurniawan, \& Sandra, 2017; Rahayu, Harto, \& Joko, 2014; Wirda, Ghani, \& Khaldun, 2015). In addition, other learning models, such as the 5E learning cycle model, have also proven to be effective in increasing student SPS (Putra, Widoretno, \& Prayitno, 2015).

Besides the models, appropriate approaches and learning methods can also improve students' science process skills. A scientific approach is an approach that includes aspects of SPS. This approach is felt to be able to increase student SPS. This approach is also the recommended approach to be used in the 2013 curriculum. The use of this approach has also been proven to increase student SPS based on the results of Febriana's research (Febriana, 2017). Good learning methods must also support the right model and approach. Experimental and demonstration methods are teaching methods that are in line with the proposed models and approaches. In addition to choosing the right model, method, and approach, the assessment instruments used must also be appropriately arranged.

\section{REFERENCES}

Akinbobola, A. O., \& Afolabi, F. (2010). Analysis of science process skills in West African senior secondary school certificate physics practical examinations in Nigeria. Bulgarian Journal of Science and Education Policy (BJSEP). 
Al-Rsa'i, M. S., Al-Helalat, K. M., \& Ali Saleh, R. S. (2017). Science Processes Skills Acquisition \& Relationship thereof with Academic Level \& Students' Attitude towards the Laboratory. Journal of Studies in Education. https://doi.org/10.5296/jse.v7i3.11562

Aslan, O. (2015). How do turkish middle school science coursebooks present the science process skills? International Journal of Environmental and Science Education. https://doi.org/10.12973/ijese.2015.279a

Delen, I., \& Kesercioğlu, T. (2012). How middle school students' science process skills affected by Turkey's national curriculum change? Journal of Turkish Science Education.

Febriana. (2017). Penerapan Pendekatan Saıntıfık untuk Menıngkatkan Keterampılan Proses Saıns dı Kelas IV SD. Jurnal Pendidikan Guru Sekolah Dasar, 1(1), 142-155. https://doi.org/10.17509/jpgsd.v1i1.6554

Hirça, N. (2012). The Influence of Hands on Physics Experiments on Scientific Process Skills According to Prospective Teachers' Experiences. European J of Physics Education.

Jones, M., Andre, T., Negishi, A., Kubasko, D., Bokinsy, A., \& Superfine, R. (2003). Hands-on science: The impact of haptic experiences on attitudes and concepts. National Association of Research in Sceince Teaching Annual Meeting. Philadelphia.

Jumadi, J., Sunarno, W., \& Aminah, N. S. (2018). Pengembangan Modul IPA Berbasis Keterampilan Proses Sains untuk Menıngkatkan Kemampuan Berpıkır Krıtıs Peserta Didik Kelas VII SMP pada Materı Kalor. INKUIRI: Jurnal Pendidikan IPA. https://doi.org/10.20961/inkuiri.v7i2.22986

Khaeruddin, Mohamad Nur, W. (2016). Fostering Critical Thinking Skill through Optimizing Science Process Skills in Physics Learning. IOSR Journal of Research $\mathcal{E}$ Method in Education (IOSR-JRME). https://doi.org/10.9790/7388-060608103108

Muliyani, R., Kurniawan, Y., \& Sandra, D. A. (2017). Peningkatan Keterampilan Proses Sains Terpadu Siswa melalui Implementasi Levels of Inquiry (LoI). Tadris: Jurnal Keguruan dan Ilmu Tarbiyah. https://doi.org/10.24042/tadris.v2i2.1904

Olusegun, S. (2015). Constructivism Learning Theory: A Paradigm for Teaching and Learning. IOSR Journal of Research \& Method in Education Ver. I. https://doi.org/10.9790/7388-05616670

Putra, A. H. I., Widoretno, S., \& Prayitno, B. A. (2015). Peningkatan Keterampilan Proses Sains (KPS) Dasar Siswa Melalui Penerapan Model Learning Cycle 5e Di Kelas Viii G Smp Negeri 22 Surakarta Tahun Pelajaran 2012/2013. Jurnal Pendidikan Biologi, 7(1), 89-100.

Rahayu, E. ., Harto, N., \& Joko, S. (2014). Upaya Meningkatkan Keterampilan Proses Sains Siswa Dengan Menggunakan Model Inkuiri Terbimbing Pada Mata Pelajaran Fisika Kelas X-10 di SMA 2 Kudus Tahun Ajaran 2012/2013. Jurnal Pendidikan Sains Indonesia, 3(2), 131-142.

Remziye Ergul, Simsekli, Y., Calis, S., Ozdilek, Z., Gocmencelebi, S., \& Sanli, M. (2011). The Effects Of Inquiry-Based Science Teaching On Elementary School Students' Science Process Skills And Science Attitudes. Bulgarian Journal of Science and Education Policy (BJSEP).

Rezba, R. J., Sprague, C., \& Flel, R. (2003). Learning and Assess Science Process Skill. Lowa: Kendall/Hunt.

Rostina, Su. (2014). Statistika Penelitian Pendidikan. Bandung: Alfabetha.

Rustaman, N. (2005). Strategi Belajar Mengajar Biologi. Malang: IKIP Malang.

Safaah, E. S., Muslim, M., \& Liliawati, W. (2017). Teaching Science Process Skills by Using the 5-Stage Learning Cycle in Junior High School. Journal of Physics: Conference Series. https://doi.org/10.1088/1742$6596 / 895 / 1 / 012106$

Subali, B. (2015). Pengukuran Kreatıvitas Keterampilan Proses Sains dalam Konteks Assessment for Learning. Jurnal Cakrawala Pendidikan. https://doi.org/10.21831/cp.v1i1.4196

Sukmadinata, N. S. (2012). Metode Penelitian Pendidikan. Bandung: PT Remaja Rosdakarya.

Turiman, P., Omar, J., Daud, A. M., \& Osman, K. (2012). Fostering the 21st Century Skills through Scientific Literacy and Science Process Skills. Procedia - Social and Behavioral Sciences. 
https://doi.org/10.1016/j.sbspro.2012.09.253

Widodo, W., Rachmadiarti, F., \& Hidayah, S. N. (2017). Buku Guru Ilmu Pengetahuan Alam SMP/MTs Kelas VII. In Kementrian Pendidikan dan Kebudayaan.

Wirda, Ghani, A., \& Khaldun, I. (2015). Penerapan Pembelajaran Model Problem Based Learning (PBL) untuk Menıngkatkan Keterampilan Proses Sains dan Motıvası Belajar Siswa pada Materı Alat-Alat Optık. Jurnal Pendidikan Sains Indonesia, 2(2), 80-86.

Wisudawati, \& Sulistyowati. (2015). Metodologi Pembelajaran IPA. Jakarta: PT Bumi Aksara.

Wright, G. B. (2011). Student-Centered Learning in Higher Education. International Journal of Teaching and Learning in Higher Education. https://doi.org/10.1080/03075079312331382498 